\title{
Deviance and the Subversive Grotesque in Barbara Gowdy's We So Seldom Look on Love
}

\author{
Hilde Staels, KU Leuven, Belgium
}

\begin{abstract}
This article examines We So Seldom Look on Love, a short story collection by the Canadian author Barbara Gowdy who displays a strong interest in extreme forms of physical and mental deviance in relation to the act of looking. Discursive forms are analyzed that revolve around the tyranny of the normative gaze and the fear of deviance, the bounded bodily ideal as opposed to the body in pieces. Kaja Silverman's psychoanalytic theory of the field of vision in relation to deviant bodies throws light on these recurring issues in Gowdy's short stories. Additionally, contemporary theories of the grotesque inform the analysis of the Gothic-Carnivalesque, a subversive strategy with which the author provokes our perception and classification of humans, identities, and sexes. The collection will be shown to culminate in the final story that contains a scene in which a female protagonist bestows "the productive look" (Silverman) upon her transsexual husband.
\end{abstract}

Keywords: Barbara Gowdy, We So Seldom Look on Love, Deviance, the GothicCarnivalesque, the productive look.

I. The neo-Gothic, the grotesque, and the fear of deviance

The title of Barbara Gowdy's short story collection We So Seldom Look on Love (1992) puts forward its major preoccupation with the acts of seeing and being seen as well as its deviant protagonists' desire to be loved. The stories by the celebrated Canadian author consistently revolve around the way in which freaks of the past and other "monstrous" characters, whose behavior or bodies deviate from the cultural norm, perceive and are perceived via images. The physically or spiritually aberrant characters are portrayed as products of the perception of onlookers who are themselves associated with the belief 
systems and speech types of a cultural elite that belongs to the white middle class. The judiciary, the medical world, the Presbyterian Church, and the bourgeois family are institutions that represent the high seriousness of official culture and the discourse of authority. These institutions classify humans, identities, and sexes on the basis of binary oppositions and are shown to be afraid of anomalies. In other words, Gowdy's fiction illustrates the way in which the concept of the norm "permeates our contemporary life" and is part of an "ideological consolidation of the power of the bourgeoisie" (Davis 1997, 26).

In We So Seldom Look on Love, Gowdy highlights a bourgeois culture's easy dichotomies that are the basic units of our thought and underlie acts of visual violence against others. Gowdy draws attention to our cherished categorical either/or distinctions between self/other, sameness/difference, human/non-human, normal/abnormal and masculinity/femininity by means of which we see and try to comprehend reality. She also, however, disturbs the familiar linguistic categories with which we perceive and order reality by parodically using conventions of the Gothic and, to a greater extent, the grotesque with its defamiliarizing effect. This transhistorical aesthetic category revolves around perception in relation to the problem of cognition and is therefore perfectly in tune with Gowdy's portrayal of an onlooker's paradoxical response to seeing characters whose "monstrous" bodies or minds violate cultural classifications. Ordinary perspectives in the context of the characters' known, everyday bourgeois world are destabilized in a confrontation with grotesque images. In this short story collection, Gowdy uses conventions of the Gothic and the grotesque parodically to critique cultural anxieties regarding difference. This target of parody, as Linda Hutcheon amply illustrates in her analyses of postmodern fiction, has been prominent in contemporary art since the 1990 s.

Some critics have already pointed out Gowdy's reliance on the conventions of the Gothic and the grotesque in a few stories from $W e$ So Seldom Look on Love. To Justin D. Edwards, Gowdy's fiction refers to the body as "a platform for identity" that "can be transformed" (Edwards 2005, 152). He describes Gowdy's neo-gothic short fiction as "an extremely subversive streak" (p. 164) in which the grotesque is "both a source of freedom and fear" that aims at interrogating "our 
ideas about monstrosity" (p. 159). So far, only two stories from the collection have been subject to extensive literary criticism. Hilde M. Zitzelsberger specifically focuses on the freak as medical oddity in "Sylvie" and Lee Parpart compares the title story with the film version of 1997 entitled Kissed. Maria Jesus Hernaez Lerena is the only literary critic who deals with the entire collection and proposes to study the links between the nature of the short story genre and the literary grotesque (Lerena 2003, 718). The present article adopts a different theoretical angle to discuss the motif of perception in relation to Gowdy's complex use of the grotesque mode. Her continuous blending of the demonic grotesque and carnivalesque or folk grotesque, with instances of comic relief and humor as an underlying subversive strategy, is innovative and needs to be studied further. A close examination of the way in which Gowdy mixes the two types of grotesque is especially appropriate as the "Gothic-Carnivalesque" appears to be a favorite strategy of several twenty-first-century writers of neo-gothic fiction. Catherine Spooner's recent theory about the contemporary "Gothic-Carnivalesque" in which the monstrous transgression of boundaries is treated both in a terrifying and irreverent or downright comic manner will be introduced in the next section.

The aim of this article is not only to investigate Gowdy's complex use of the grotesque on the basis of recent theories about this mode, but her stories which revolve around the perception of disturbing images will also be illuminated by Kaja Silverman's psychoanalytic examination of the field of vision. To a lesser extent, this analysis will rely on insights from theorists of disability whose publications on freaks of the past appeared during the 1990s. Rosemarie Garland-Thomson and Elizabeth Grosz, for instance, will be shown to offer socially engaged theories about extreme forms of corporeal deviance in contemporary art. Their ideas throw an interesting light on Gowdy's preoccupation with excessive physical and mental deviance whereas Kaja Silverman's notions are especially relevant in dealing with the act of looking. These theorists' insights will inform the analysis of discursive forms with which Gowdy's characters refer to the "horror" of physical fragmentation as opposed to the classical image of the body as a seamless whole that is unconsciously idealized. The collection is clearly held together by these issues, for most stories both revolve around the tyranny of the 
normative gaze and the fear of deviance, and the bounded bodily ideal as opposed to the body in pieces. Yet the final and previously unpublished story entitled "Flesh of My Flesh" offers an additional and important dimension to the collection for, as will be shown, it culminates in "the look's potentially transformative powers" as theorized by Kaja Silverman (Silverman 1996, 227).

\section{Socially devalued bodies and the act of looking}

In The Threshold of the Visible World, Silverman extensively examines the field of vision in the context of bodies that are culturally despised. She relies on Jacques Lacan who understands one's sense of being in terms of being seen by others in Four Fundamental Concepts of Psycho-Analysis. Like Lacan, Silverman distinguishes between the look or the human eye, which is associated with the subject's individual desire, and the cultural gaze that is "independent of any individual look" (Silverman 1996, 134). The human eye, which opposes the ideal image with "the body in pieces" (p. 226), represents to Silverman "the most classic perceptual locus of disavowal" (p. 163). Visual authority is conferred on the cultural gaze which, according to her, is like a photographic image that "often imposes upon the subject an unwanted identity" (p. 57). The social gaze, being caught in a cultural representational system, underpins difference, among other things, in terms of gender, race, class, and sexual preference.

With regard to the perception of culturally devalued bodies, to which the normative subject might respond with horror and contempt (Silverman 1996, 113), Silverman ultimately proposes an ethics of the productive look. She imputes to the look a creative potential, for she says that it can offer the locus for "a resistant and even transformative vision" (p. 160). Someone with a productive vision recognizes the deviant other within the self. The creative potential of the human eye underlies Silverman's ethics of the productive look, which implies that humans can resist discourses that "seek to master and regulate" the human eye (p. 156) and consciously bestow "the active gift of love" upon people whose bodies deviate from the cultural norm. Love, according to Silverman, is "the signifier for the productive look" (p. 199) and the look can confer this active gift of love upon people that are used to being disdained because of their deviant bodies (p. 227). 
Silverman's claim that "productive looking necessarily entails ... the opening up of the unconscious to otherness" (Silverman 1996, 184) coincides with Julia Kristeva's psychoanalytic model for an ethics that embraces difference in Leur regard perce nos ombres. In this recent co-publication with Jean Vanier, which has not yet appeared in English translation, the psychoanalytic and literary theorist Julia Kristeva explores people's fear of proximity to the disabled. She says that people fear disability because it confronts them with their shadow, that is, their own mortality and unconscious fear of physical or spiritual deterioration. In her view, it is their fear of being invaded by deficiency that causes human beings to exclude the deviant other and keep him/her at a proper distance from the self.

In dealing specifically with onlookers' anxiety towards freaks of the past, Rosemarie Garland-Thomson says that such people with anomalous human bodies used to be displayed in sideshows until the 1940s because their "hybridity, along with excess and absence" (Garland-Thomson 1996, 5) threatened cultural beliefs about what constitutes the human. The congenitally physically disabled, such as the legless and/or armless and conjoined twins, are products of perception that violate "the categorical boundaries that seem to order civilization and inform individuality" (p. 5). These freaks are socially marginalized because they rupture cultural boundaries that rely on what is known, proper, and normal. Garland-Thomson associates the liminality of the freak with the grotesque as a liminal aesthetic category whose function in postmodern fiction is to blur accepted categories, relinquish the ideology of unity and sameness, highlight new possibilities, and accommodate new forms of identity (Garland-Thomson 1997, 112-113).

In line with Garland-Thomson, Elizabeth Grosz treats the human being who suffers from the most severe physical disorder as someone who imperils "categories and oppositions dominant in social life" and definitions we rely on to "classify humans, identities, and sexes - our most fundamental categories of self-definition and boundaries dividing self from otherness" (Grosz 1996, 57). To Grosz, the "normative viewer's ambiguous response of horror and fascination is elicited by his/ her identification" with the monstrous other, for the freak embodies everything that a person wishes to exclude "to make the bounded, category-obeying self possible" (p. 65). In arousing a simultaneous 
response of repulsion and fascination, the solitary and socially marginalized freak, who populates much contemporary fiction, is a boundary creature that is commonly associated with the aesthetic category of the grotesque.

\section{Contemporary theories of the grotesque}

The grotesque emerges in contemporary art forms that deal with "normal" people's perception of deviance. Like the Gothic, the grotesque is an aesthetic category that revolves around the relationship between perception and knowledge, as well as the interruption of certainty, understanding, and meaning in a confrontation with "monstrosity," which ruptures the boundaries of the known. Fiction containing the Gothic and grotesque modes therefore mixes the conventions of realism with those of fantasy. To Rosemary Jackson, who studies fantasy as a literature of subversion, the Gothic and grotesque commonly explore whatever escapes "knowledge, comprehension, reason," established "through the 'eye' and the 'I' of the human subject whose relation to objects is structured through the field of vision" (Jackson 1981, 45). In present-day fiction, writers who rely on the grotesque intermingle the familiar and normative with the alien and unexpected so as to provoke received ideas and normal expectations.

Contemporary theorists of the grotesque, who emphasize the impossibility of providing a univocal definition of the concept, put forward its affinity with paradox. They rely on Philip Thomson's influential study of the grotesque in which "the paradox of attraction/ repulsion" (Thomson 1972, 51) is shown to be basic to this mode, and whereby the mixture of incompatibles remains unresolved. Theorists generally emphasize the paradoxical combination of fascination with fear or shock, distaste and wonder, in the perception of monstrosity. Excess, exaggeration, and hyperbolism are devices with which the grotesque mode disrupts boundaries, unsettles the reader's common perception of reality, and causes emotional disorientation.

Modern ideas about the nature of the grotesque in art are indebted to the early theories of Wolfgang Kayser and Mikhail Bakhtin. Their definitions of the grotesque as an aesthetic category, however, are quite distinct from each other. To Kayser, who developed his theory on the 
basis of the Romantic or demonic grotesque in Hoffmann's Night Tales, the grotesque in its purest form is alien, inhuman, and uncanny. The Romantic grotesque instills fear of life rather than death and is a manifestation of impersonal demonic powers and horror that erupt from the unconscious. Mikhail Bakhtin analyzes the medieval and Renaissance grotesque in relation to the culture of folk humor and the spirit of carnival, with its "lowering of all that is high, spiritual, ideal, abstract ... to the material level" (Bakhtin 1984, 19) and its ritualistic inversion of social and moral conventions. In his study of Rabelais, he emphasizes the joyful, comic, and regenerative features of the folk grotesque or carnivalesque.

Critics point out that both traditional theories are reductive because Kayser and Bakhtin largely ignore the ambiguity and indecision that is typical of the grotesque. Geoffrey Galt Harpham observes that the grotesque disrupts our conventional logic that "is built on an avoidance of contradiction" (Harpham 1982, 53) and that it forms "a species of confusion" (p. XV). Harpham makes the important comment that the grotesque in late-twentieth-century fiction possesses a transformative and creative potential. He claims that the subversive strategy of the grotesque leads to discovery and the readers' "enlargement of the mind" (p. 191). Frances Connelly, a professor of modern art history, has recently published a study of the grotesque in contemporary Western art and culture in which she also emphasizes the transformative nature of the grotesque. Connelly treats the grotesque as a cultural phenomenon that fuses an artistic form with social and ethical questions. In her view, contemporary art displays a renewed interest in the grotesque because we live in a time of globalization when a culture's easy dichotomies are no longer elucidating. She notices that the grotesque with its "urge to turn the world upside down and to play among broken boundaries" is still very influential (Connelly 2012, 23).

Catherine Spooner similarly recognizes a marked preoccupation with the grotesque in present-day fiction (Spooner 2006, 29). In her study of contemporary gothic literature, Spooner applies the term "GothicCarnivalesque" to fiction that combines gothic conventions with the folk or comic grotesque. The latter is characterized by "freakish heroes and heroines" and the "celebration of bodily excess" (p. 68). These freaks may be read as a trope of a feared otherness within and outside 
the self, as Mary Russo suggests in her book on the grotesque in relation to gender issues (Russo 1994, 85). Spooner describes the Gothic-Carnivalesque in present-day fiction as continuously shading the sinister into the comic and vice versa with a view to arousing "sympathy for the monster" (Spooner 2006, 69). She relies on Avril Horner and Sue Zlosnik's study of contemporary neo-gothic fiction in which parody of the Gothic is conflated with comic relief and humor that are part of the comic grotesque. Horner and Zlosnik depend on Linda Hutcheon's influential definition of parody in A Theory of Parody as repetition with critical difference yet believe she minimizes the importance of parody's comic dimension. When something that used to be perceived as monstrous is turned to creative purpose, in Horner and Zlosnik's opinion it is "because parody can offer Gothic a comic turn" (Horner and Zlosnik 2005, 12). Their study of neo-gothic fiction, in which parody of the Gothic is combined with the demonic and comic grotesque, results in the finding that this kind of fiction "allows a fresh perspective on a changing world, one of accommodation rather than terrified apprehension" (p. 12).

In the following section, Gowdy's We So Seldom Look on Love will be discussed as representative of the Gothic-Carnivalesque. Each story from Gowdy's collection will be treated separately, though common thematic and formal aspects will be put forward. Formally, the stories will be shown to rely on the combination of conventions belonging to the demonic and folk grotesque and to shift from the sinister into the comic. Particularly interesting is the self-reflexivity of the narratives whereby the grotesque is shown to revolve around the perception of disturbing images of difference. The subversive grotesque or Gothic-Carnivalesque mode is a strategy with which Gowdy not only challenges the limits of propriety but also calls into question existing social roles and hierarchies as well as social values and norms that shape her characters' perception.

\section{$I V$. The tyranny of the gaze and the fear of deviance}

From the first story onwards, Gowdy's We So Seldom Look on Love is concerned with the act of looking as being anything but neutral. "Body and Soul" deals with a girl named Terry who, being born blind, is unaware of people's difference. The latter is conveyed in the omniscient 
narrator's reflection that Terry "took it for granted that everybody had the same face" (Gowdy 1993, 7) and that "she can't grasp the idea of black against white" (p. 21). Here, Gowdy plays with the double meaning of the verbs "to see" and "to grasp." Categories and linguistic distinctions only make sense to people who impose a specific meaning, or who project binarisms, on a reality that they are able to perceive. People's reliance on binary distinctions is conveyed through the reference to "black against white." This link between seeing and imposing dichotomies on reality is reiterated in the final story entitled "Flesh of My Flesh." Its protagonist, Marion, who needs to come to terms with the reality that she married a transsexual, looks at her husband, Sam, "but it's so dark it doesn't make any difference” (p. 207).

A doctor in "Body and Soul" normalizes Terry by giving her sight. Immediately after her cataract operation, Terry sees that "Aunt Bea's face is different from the doctor's. Men must have different faces from women, she thinks" (Gowdy [1992], 1993, 24). The connection between perceiving and conceiving distinctions is also clear from Terry's statement "I know, I see it," when the deviant girl called Julie tells her there's a red car in the parking lot (p. 29). Terry begins to understand what it means to have a visual identity when she is able to see her specular reflection. She looks at the image in the mirror and perceives a purple birthmark on one side of her face. She likes her deviant skin pigmentation, but Aunt Bea, whose gaze relies on cultural representations, tells her "That's coming off ... It'll be the same colour as the rest of your skin" (p. 26).

Aunt Bea, the aged foster mother of both Terry and Julie, classifies the latter as "a retard" (Gowdy [1992], 1993, 10). A Presbyterian worshipper, Aunt Bea likes the hymn "All Things Bright and Beautiful" (p. 18) because it gives expression to the cultural ideal. In spite of her own minor disabilities, for she is no longer capable of seeing or hearing properly, the discursive repetition of "(all) right" gives expression to her constant desire to make what she sees coincide with what she knows. It conveys her common desire for fixity, order, and a stable meaning, that is, aspects that the grotesque lacks. When Aunt Bea is confronted with a disorienting, shocking image, such as Julie drilling a hole into her head, the narrator comments that Bea "doesn't know yet what she is seeing" (p. 34). The story ends with a scene in which Gowdy plays with the 
double meaning of the verb "to grasp" in the context of a spectacle of otherness, for Aunt Bea looks on a new foster girl with an artificial arm "failing to grasp it" into the socket (p. 36). The characters' repetitive failure to understand accurately when confronted with images of deviance adds comic relief to the grotesque.

\section{$V$. The bounded bodily ideal vs. the body in pieces}

In "Presbyterian Crosswalk," the able-bodied mother of the disfigured Helen is associated with the norms of the bourgeoisie and the medical world. Yet the mother's compulsive desire for perfect order and her excessive urge to eradicate the mess of life, which her daughter constantly reminds her of, is itself comically grotesque. To Beth, Helen's only friend, who is a practicing Presbyterian with a healthy body, Helen's waterhead and waddling body is a disturbing reality that Beth believes can be normalized by chanting "Water go away." The fact that the girls believe the song actually reduces the waterhead is one of the comic events in the story.

Ironically, it is Helen who states "At least I'll die in one piece" (Gowdy [1992], 1993, 68) after having witnessed a boy being run over by a car. She is shocked at seeing the spectacle of Kevin Legg's heavily bleeding body in pieces. Her reaction converges with Silverman's insight that "values like "wholeness' and "unity" are evoked by "the successful imaginary alignment" with the ideal of the lovable visual image, which is sustained by the gaze (Silverman 1996, 20) and "the body in bits and pieces" provides "the imaginary construct through which the subject indirectly apprehends both his or her distance from the mirror, and his or her manque-à-être" (p. 63).

Beth's sloppy grandmother also has a body that is in pieces, for "a quack ... ripped out her vocal chords and the underside of her tongue" (Gowdy [1992], 1993, 63). Unable to speak, the grandmother writes down a telephone message for Beth that seems to be about Helen's anticipated death and liver donation to Kevin. When the grandmother taps a pencil to communicate to the caller "I'm taking it all down" (p. 80 ), the verb refers both to her act of putting something down in writing and to the process of dismantling, which reiterates the motif of deformed bodies lacking wholeness. The obsession with stability and 
bodily integrity is so exaggerated in "Presbyterian Crosswalk" that it gains a comic effect.

The motif of bodies lacking unity is particularly obvious in "The Two-Headed Man" and "Sylvie," which are stories about so-called monsters of excess named Samuel/Simon and Sylvie/Sue respectively. ${ }^{1}$ Gowdy hyperbolizes deviance in portraying these circus freaks of the past, who are scientifically labeled as "autosites-parasites," and who may be interpreted as a trope of people's feared otherness within and outside the self. The monstrous characters themselves wish to be normalized, for they desire to be loved by those who belong to the cultural elite.

When Sylvie joins a carnival freak show in the 1940s, she notices "the blend of repulsion and attraction that is in every face" (Gowdy [1992], 1993, 50). By contrast, to the physician John Wilcox, who looks on her "monstrosity" from a scientific angle, Sylvie is an interesting medical specimen. Wilcox's question "when can he see her again?" (p. 49) plays with the meaning of seeing as a verb of perception and the physician's role as consultant. The doctor with the comic name imposes his cock's will, that is, his rational power and normative gaze, on Sylvie in telling her that she can be normalized. The repetition of such verbal forms as "he will" and "they are going to" convey John's aspiration toward mastery and his scientific will to regulate the anomaly. Before the act of severing Sue from Sylvie, which belongs to the demonic grotesque, Wilcox's penetration of Sylvie/Sue's vagina with his "lightning-rod penis" results in a "spectacular" orgasm experienced by each that is conveyed through the kind of sexual excess typical of the folk grotesque (pp. 56-57).

Without considering Sue, the male gaze sees a resemblance between Sylvie and the movie star Vivien Leigh who incarnates "an idealized image of the body" (Silverman 1996, 70) and is therefore the opposite of the grotesque. Wilcox's mortifying gaze is said to "bore into" Sylvie (Gowdy [1992], 1993, 60) prior to the surgical severing of Sue, an act of violence that forces Sylvie within the "expected corporeal boundaries" (Zitzelsberger, n.p.). Before the operation, Wilcox's utterance directed at Sue, "This is it" (Gowdy [1992], 1993, 60), betrays his perception of the latter as simply a superfluous thing. He then urges Sylvie/Sue to be "brought to the centre of what seems like a stage" (p. 60), where she is a spectacle of the cosmetic surgeons' clinical stare. 
The name Sue bears a similarity with the Greek word zoè, which means "life" or simply "being alive." As a child, Sylvie "squashed the life out of" insects or worms after which she flattened them until they resembled photographic images that she glued into a scrapbook (Gowdy [1992], 1993, 50). Prior to the surgical severing of Sue, before "going under" (p. 61), Sylvie has a magnified vision of fireflies that are alive and shining. In the context of the normalization of her body, the expression "going under" not only means losing consciousness but also suffering defeat or destruction as a victim of the male gaze. Indeed, after the separation from Sue, Sylvie will be haunted by the ghost of her twin sister. Her spirit is downcast, which suggests that she does not rejoice over her illusory coherent identity but mourns over the loss of Sue as the living, inescapable otherness within herself.

Similarly, in "The Two-Headed Man," the parasitic head named Simon is shown to be the doppelgänger or the unrecognized aspect of the autositic head called Samuel. Gowdy again uses the gothic motif of the doppelgänger to deal with the relationship between the self and the feared inner stranger. The heads are represented as two distinct characters and the story is a first-person narrative, alternatively told by Samuel and Simon whose speech types are initially opposed to one another. As in the story "Sylvie," the conjoined subject is ambiguously one identity and two, but does not wish to speak in terms of "we." Samuel's obsessive longing to have a unified body, without the extra head and thus "be like other men" (Gowdy [1992], 1993, 113), is in line with his bourgeois ideology. Prior to his beheading of Simon, an act that conveys the demonic grotesque, Samuel sides with the normative judgment of the legal system, the medical world, and religion. Simon, by contrast, hates doctors and exclaims: "Scientists can't wait for me to die so they can open me up and get a good look ... Doctors will tell you I can't do fuck all, it's Samuel who's the whole man with the limbs and organs" (pp. 102-103). Simon's excessively ribald language is typical of the folk grotesque whereas Samuel's discourse is extremely formal, rational, and controlled so as to convey the superiority and seriousness of the high bourgeois culture that he desires to belong to.

Samuel's both demonic and comic act of sawing off his twin brother's head was supposed finally to rid him of a terrifying "monstrosity" (Gowdy [1992], 1993, 110). However, instead of guaranteeing normality 
and wholeness, Simon's abhorrent desires and affects continue to live on in Samuel's anxiety dreams and are thereby shown to belong to his dark alter ego. In addition, Simon's silenced primitive and instinctual forces uncontrollably erupt from Samuel's unconscious when the latter calls a nurse a "Goddamn bitch" (p. 109) and a surgeon an "Idiot" (p. 113). This eruption of Simon in Samuel, whereby the lower part of the latter's nature disrupts his better self, is conveyed in terms of a carnivalesque degradation of the high bourgeois culture that Samuel wishes to belong to.

Not only in "The Two-Headed Man" but also in "Lizards" does Gowdy provoke people's fear of ambiguity, uncertainty, and disorder. Once again, she duplicates the bitter laughter that paradoxically accompanies the horror of the demonic grotesque and provides humor as well as comic relief that are part of the folk grotesque. Thus "Lizards" explores the horror of corporeal disintegration in the context of the body of Marion's mother being shot to pieces. In addition, the girl Nicky is beheaded by the blade of a spinning ceiling fan while sitting on the shoulders of the giant Ed. Nicky's mother Emma is haunted by this grotesque event as it is "the biggest shock" of her life (Gowdy [1992], 1993, 127). Yet the horrifying image is attenuated by comic amusement, considering the gigantic Ed's unintentional ambiguous statement "I've got some time to kill" (p. 135) before causing the gruesome incident. Emma, who is haunted by the memory of her daughter's severed head, believes in "lizards - the ones with break-away tails that grow back - as representing the highest order of life" (p. 140). She hereby gives expression to the ideal of the self as a seamless whole with which all the characters in the collection are shown to be obsessed. Gowdy's grotesque strategy makes the reader critically aware of how strongly ingrained this aspiration to wholeness and unity is in people's lives.

\section{A comic inversion of the abject}

"We So Seldom Look on Love," the title story of the collection, comically inverts people's illusory desire for a singular and coherent identity and in doing so, Gowdy actually reaffirms the dominant pattern in the collection. In dealing with the psychic aberration of necrophilia, 
she relies on conventions of the Gothic and the demonic grotesque. Unlike the characters in the preceding stories, the female necrophile celebrates the idea of corporeal disintegration and feels no desire to be a human being who is "in one piece" (Gowdy [1992], 1993, 145). A classical beauty, the protagonist feels victimized by the gaze that mortifies her body. By contrast, the dead make her feel "better, more confident" (p. 154). She can be who she is when she makes love to the dead because they "can no longer see" (p. 17), which is actually a line from the story "Body and Soul" that casts some light on the title story. It is no coincidence that the necrophile chooses Carol as a friend during adolescence because of her unfocused "wandering eye ... looking everywhere at once" (p. 147) and that she adds "Normally, I don't like looking people in the eye" (p. 151).

The necrophile is attracted by what people perceive to be monstrously disturbing, for she is only capable of passionate eros with fresh male corpses. She is turned on by "the smell of danger" (Gowdy [1992], 1993, 154) and relentlessly places herself at the very margin of civil society by compulsively merging with the abjected other. In Powers of Horror, Julia Kristeva introduces the notion of the abject as a subset of the grotesque to refer to an otherness that is expelled from the self because it is perceived as disgusting. Thus seeing corporeal waste such as excrement or menstrual blood as well as an infected or decaying body is repulsive, for it reminds people of their own mortality, animality, and corporeality. In Kristeva's view, the dead show us what we permanently thrust aside in order to preserve our individual identity. The abject is the radically excluded object, the repressed not-I-in-me that is experienced as a threat to the social system, the existing order, and one's human identity. According to Kristeva, one's encounter with a human corpse is feared because it is "the most sickening of wastes ... it is death infecting life" (Kristeva 1982, 3-4), it "represents fundamental pollution" and is "an object of abomination" (pp. 109-110). Bourgeois society considers necrophilia to be a perverse form of sexuality, as it involves the dangerous crossing of boundaries between life and death, the human and the non-human, the pure, clean self and the filthy other.

Paradoxically, the first-person narrator in Gowdy's title story claims that her romantic passion for, and sexual encounter with, a dead unseeing person makes her burst with energy. Before each sexual 
intercourse with a newly dead young man in a morgue, she performs a delirious dance that symbolizes an intoxicating fantasy of formlessness, a grotesque body in flux. The protagonist imagines her body being in pieces during her ritualistic fusion with decomposing matter, an act that she perceives as part of a transitional stage and a revitalizing process. Gowdy hereby ironically inverts Bram Stoker's Dracula, for instead of a soulless male vampire who gains life by feeding on the blood of young living girls, she portrays a classical beauty with a soul who claims to undergo a regenerating metamorphosis during her nightly sexual encounter with a fresh male corpse.

This short story contains several paradoxes, for the eroticizing of the abject which is part of the demonic grotesque has a regenerative function that is typical of the folk grotesque. The fantasy of having sex with a dead unseeing man makes the protagonist feel alive, whereas she feels violated when subjected to the gaze of live human beings. As paradox is basic to the grotesque, it come as no surprise that the sexually deviant narrator ends her confession with an oxymoron, claiming that she has "found no replacement for the torrid serenity of a cadaver" (Gowdy [1992], 1993, 159).

Gowdy relies on the Gothic and the demonic grotesque to describe the necrophile's psychic transgression of the known, the conventional, and the understood in horrifying extremes of human behavior. Her exploration of the abject by means of the demonic grotesque is quite common in contemporary grotesque art forms (Connelly 2012, 115). Yet Gowdy not only reduplicates the bitter laughter that paradoxically accompanies the horror of the demonic grotesque. She attenuates the horror and disgust that necrophilia normally entails by referring to joy and spiritual renewal through the sexual act, which is typical of the carnivalesque. According to Horner and Zlosnik, such inversion of the abject is a feature of the comic turn in the contemporary Gothic (Horner \& Zlosnik 2005, 166).

The folk grotesque is also present in the description of Matt, the medical student who becomes obsessed with the young woman's alterity. His growing fascination with the protagonist's psychic abnormality not only reveals the content of his bourgeois unconscious, but his lovemaking while wearing a Dracula mask also involves a carnivalesque degradation of the high bourgeois culture that the medical student 
represents. When Matt is about to hang himself because his love for the protagonist is unrequited, she punches his leg. The incongruity of taking a punch at Matt's leg, considering the predicament, is a source of comic amusement. Additionally, humor is provided by the necrophile's subsequent incapacity to express her love for Matt, except when she imagines his legs being lifeless.

\section{The act of staring}

In contrast to the necrophile in the title story, the female exhibitionist's sense of self-worth in "Ninety-Three Million Miles Away" depends on a man's gaze. Ali suffers from a low self-image, for what she sees in the mirror is the misshapen body of "a pathetic little woman with pasty skin and short legs" (Gowdy [1992], 1993, 99). Each day, she opens the drapes of her apartment window and waits until a "respectable" surgeon (p. 90) on the opposite side opens his drapes in order to watch her monstrous erotic display. The stranger voyeuristically looks on her spectacular orgasms from a safe distance with scientific fascination, as if this starer-staree dynamic is part of a carnivalesque freak show. His binoculars function, like a camera, as a metaphor for the gaze that sees a grotesque spectacle. Ali makes what Silverman calls "a spectacle out of spectatorship" (Silverman 1996, 59) and reflects "The whole show was for him - cunt, ass, mouth, throat offered to his magnified vision" (Gowdy [1992], 1993, 94). The discourse of the folk grotesque or carnivalesque with its emphasis on the body's orifices is used in the description of the exhibitionist's spectacular orgasms and clearly produces humor.

In this story, the staring surgeon no longer comes across as an authority, but he becomes degraded instead, like the medical student in the title story, for as Rosemarie Garland-Thomson says: "the loss of self-possession and often inadvertent breach of social etiquette inherent in the stare mark the startled viewer as vulnerable and inappropriate" (Garland-Thomson 2006, 179). Matt's obsession with the necrophile in the title story and his intense staring even causes an erasure of the distinction between himself as a medical authority and the deviant other, that is, the I and the not-I-in-me. This obsession slowly leads Matt to an estrangement from the self whereby the reader witnesses a "renegotiation 
of the ego/other axis" (Silverman 1996, 192), symbolized by Matt gradually redirecting his stare towards the uncanny other within himself: "He was glued to the dresser mirror. In the last weeks of his life he stared at himself in the mirror without the least self-consciousness. He focused on his face ... When we made love ... He stared into my eyes, riveted ... by his own reflection" (Gowdy [1992], 1993, 156). Matt's recognition of his secret deviant otherness ultimately ends in his wish to annihilate the self. It does not seem to be coincidental that this disturbing title story is immediately followed by "Flesh of My Flesh," which depicts a healing and liberating encounter between the self and the other instead.

\section{Accommodating otherness}

"Flesh of My Flesh," the collection's final story, culminates in the productive look as theorized by Kaja Silverman. It is also a story in which the subversive grotesque clearly offers "a fresh perspective on a changing world, one of accommodation rather than terrified apprehension" (Horner \& Zlosnik 2005, 12). The horror in the story is aroused by Marion's disgust at seeing her transsexual husband's dildo. Yet the horror of the demonic grotesque is attenuated by instances of the folk grotesque, such as her female friend's excessive interest in Marion's first husband whose penis has the size of a horse's.

The closing scene from "Flesh of My Flesh" describes Marion lying in bed with Sam, the man she married without knowing he was born a girl:

There's a band of grey light between the drapes, and another band flaring across the ceiling. If somebody were looking down on them, Marion thinks if, for instance, her mother's spirit was that clean, geometrical flare - they would seem like any other man and wife. They would seem content, she thinks. Peaceful, and lucky. Two people unacquainted with grief. They would seem like two happily married, perfectly normal people. (Gowdy [1992], 1993, 208-209)

The "band of grey light between the drapes" that enters the house from the outside is contrasted with a "clean, geometrical flare" in the newly wedded couple's bedroom. The clean light is the gaze associated with the camera, one that sees no more than a deceptive reflecting surface, or an intimate, friendly, and familiar reality in the house. As Silverman says, 
"When we feel the social gaze focused upon us, we feel photographically "framed" (Silverman 1996, 135), that is, forced into the boundaries of what is known. From the perspective of Marion's deceased mother, the spectacle in bed "would seem like two happily married, perfectly normal people," as satisfying as the regularity of a geometric figure. Marion imagines her mother's undistorted view of the couple, for what the mother perceives corresponds to a fixed and safe category within the dominant cultural order.

The bedroom scene makes reference to grey as an in-between color whereas the collection's first story, "Body and Soul," starts by mentioning the opposition between black and white to highlight the characters' reliance on binary distinctions. The image of grey light shining between drapes may also be associated with the opening and closing of drapes in "Ninety-Three Million Miles Away," in the context of the female exhibitionist who desires to be stared at. The image suggests that if a stranger, representing the cultural gaze, were to stare at Sam's unwanted identity from a position outside the house, he/she would be both fascinated and repulsed by the spectacle of betweenness.

The bedroom scene of "Flesh of My Flesh" puts forward a central concern in the collection, namely, that "the same image can look very different depending upon the vantage-point from which it is observed" (Silverman 1996, 177). In this closing scene, the collection's undistorted and distorted views of reality, presented by the images of grey light as an in-between color on the one hand and a "clean, geometrical flare" on the other, are juxtaposed with Marion's new perspective on her husband's liminal gender identity. Whereas Marion was initially "disoriented" (Gowdy [1992], 1993, 169) and revolted by her loving second husband's being a boundary creature with a grotesque artificial penis, she learns to recognize the other as an other (Silverman 1996, 43). Her accommodation to his in-betweenness is foreshadowed by an earlier scene in which she risks overleaping a deep crevice in a rock - a gap or in-between space that needs to be bridged - and safely lands on the other side (Gowdy [1992], 1993, 172).

Before making love, the couple's bedroom is "pitch dark, and they breathe in unison" (Gowdy [1992], 1993, 207). When Marion finally looks on Sam's disturbing hybridity without anxiety or revulsion, she is said to be "in new territory" (p. 208). Touching Sam's pubic hair, she 
says “'It's just like me,' oddly relieved” (p. 208), for she recognizes the familiarity of the alien other. While lovemaking, Marion's exclamation "Oh, my God" (p. 208) conveys her sexual pleasure and sharply contrasts with her earlier use of the same expression when she is shocked at seeing Sam's dildo for the first time (p. 170). Whereas Marion used to look at Sam "coolly and sometimes with distaste and wonder, saying to herself, 'That's a woman's shoulder. That's a woman's arm"” (p. 188) and told Sam "You're not a man" (p. 193), she learns to accept that the visual image does not coincide with her husband's "sensational ego" (Silverman 1996, 17). Marion ends up looking again, seeing differently, and thereby generously bestows the active gift of love upon Sam. Her productive look is indeed "the locus for a resistant and even transformative vision" (p. 160).

The final story from We So Seldom Look on Love most clearly illustrates Frances Connelly's finding that the grotesque figure presents new possibilities in contemporary fiction in the sense that this boundary creature functions as "a catalyst ... setting a reaction in motion" (Connelly 2012, 8). ${ }^{2}$ Indeed, in Mister Sandman (1995), a "TLS best book of the year" 3 and the first novel to appear after her short story collection, Gowdy will further explore the transformative function of the grotesque in depicting Joan Canary as a catalyst who opens the way to spiritual renewal in the lives of the other deviant members of the Canary family. ${ }^{4}$ A "monstrous" figure, Joan represents the breakdown of distinct categories and orders of being, for she is a liminal protagonist, hovering between a human being and a puppet. She is physically deformed yet strangely beautiful, neither fully alive nor dead but capable of transgressing the boundary between life and death. Through the intervention of this hybrid character in the lives of the other family members, the conventional binary distinctions between normality and abnormality, the self and the other, are gradually perceived as permeable.

In Mister Sandman, Gowdy deals with the problem of perception in the context of the uncanny effect generated by "aberrant" nonheterosexual desires. She again relies on the Gothic-Carnivalesque in describing a middle-class family's transgression of normative sexual relations in Toronto from the mid-1950s up to the mid-1970s. Interestingly, she also inserts a self-reflexive reference to her favorite strategy, the subversive grotesque, for the narrative is said to be 
"disquieting in places, there's no question about that ... her intention is to provoke" the readers of her fiction (Gowdy 1995, 304).

The literary grotesque as a heterogeneous provocative strategy was already quite prominent in twentieth-century fiction dealing specifically with issues of identity and alterity. It continues to be an attractive mode for twenty-first-century artists because it is a form of artistic expression that fits in an intellectual climate obsessed with questions regarding the representation of what is normal and human. ${ }^{5}$ The grotesque is an ideal aesthetic instrument for artists who aim at challenging the arbitrary system of cultural classifications and who articulate the subjects of undecidability or indeterminacy.

In dealing with fearful otherness, several writers of contemporary English-Canadian prose fiction clearly show a tendency to experiment with the grotesque. Yet this tendency is not highlighted in Marlene Goldman's or Cynthia Sugars's recent studies of the Gothic in Canadian literary history. These critics particularly focus on Canadian authors, both past and present, who are obsessed with ghosts and haunting but who do not seem to rely on the grotesque. However, Barbara Gowdy and other renowned authors such as Lynn Coady and Rawi Hage strikingly blend the demonic and folk grotesque while also using gothic fictional conventions. One may therefore regard Gowdy as belonging to a group of authors who demonstrate that the Gothic-Carnivalesque is a new and powerful subversive tool of transformation or emancipation from fixed societal and aesthetic norms.

\section{NOTES}

1. The story about Sylvie/Sue is based on the life of Josephine Myrtle Corbin (1868-1928), the four-legged girl from Texas.

2. This function of the grotesque is, for instance, subtly explored by Ian McEwan in Saturday, a novel that deals with anxieties since the $9 / 11$ terrorist attacks. In Saturday, the disabled Baxter, who suffers from Huntington's disease, invades the security and familiarity of Henry Perowne's home. This brain surgeon perceives Baxter as a grotesque figure, not only because of his physical and mental deviance, but also because he is a villain with an incongruous sensibility for poetry. Baxter as an aberrant and uncanny character disrupts the established boundaries of Henry's known bourgeois world, and the surgeon's fixation on the brain instead of the mind, thereby causing Henry's emotional disorientation and transformation. Indeed, after his disturbing confrontation with Baxter, who personifies the surgeon's repressed alterity, Henry becomes "alive to too many 
contradictory impulses" (McEwan 2005, 262). His spiritual transformation coincides with his memory of a visit to the Domus Aurea in Rome, which is an important spatial metaphor, as it draws attention to the transformative function of the grotesque in the novel. The Domus Aurea, Nero's underground palace, contains frescoed decorations of strange and fascinating hybrid creatures that are called grotteschi, from which the term "grotesque" is derived.

3. Margaret Atwood in the Times Literary Supplement. Mister Sandman was a finalist for both the Giller Prize and the Governor-General's Award.

4. See Staels 2012.

5. The recent publication of Justin D. Edwards and Rune Graulund's guide to the grotesque as well as Robert Duggan's recent book on the grotesque in contemporary British fiction are but a few examples of the continuing interest in the grotesque in visual art and literature.

\section{BIBLIOGRAPHY}

Bakhtin, M. 1984, Rabelais and His World, trans. H. Iswolsky, Indiana University Press, Bloomington.

Connelly, F. S. 2012, The Grotesque in Western Art and Culture. The Image at Play, Cambridge University Press, Cambridge.

Davis, L. J. 1997, "Constructing normalcy" in The Disability Studies Reader, ed. L. J. Davis, Routledge, New York \& London, pp. 9-28.

Duggan, R. 2013, The Grotesque in Contemporary British Fiction, Manchester University Press, Manchester \& New York.

Edwards, J. D. 2005, Gothic Canada. Reading the Spectre of a National Literature, University of Alberta Press, Edmonton.

Edwards, J. D. \& Graulund, R. 2013, The Grotesque, The New Critical Idiom, Routledge, New York \& London.

Garland-Thomson, R. (ed.) 1996, Freakery. Cultural Spectacle of the Extraordinary Body, New York University Press, New York.

-. (ed.) 1997, Extraordinary Bodies. Figuring Disability in American Culture and Literature, Columbia University Press, New York.

-. (ed.) 2006, "Ways of staring," Journal of Visual Culture, vol. 5. no. 2, pp. 173192.

Goldman, M. 2012, Dispossession. Haunting in Canadian Fiction, McGill-Queen's University Press, Montreal \& Ithaca, N.Y.

Gowdy, B. [1992] 1993, We So Seldom Look on Love, Flamingo, London.

—. 1995, Mister Sandman, Somerville House, Toronto.

Grosz, E. 1996, "Intolerable ambiguity: Freaks as/at the limit" in Freakery. Cultural Spectacle of the Extraordinary Body, ed. R. G. Thomson, New York University Press, New York, pp. 55-68.

Harpham, G. G. 1982, On the Grotesque. Strategies of Contradiction in Art and Literature, Princeton University Press, Princeton.

Horner, A. \& Zlosnik, S. 2005, Gothic and the Comic Turn, Palgrave Macmillan, Basingstoke.

Hutcheon, L. 1985, A Theory of Parody. The Teachings of Twentieth-Century Art Forms, Methuen, New York \& London. 
Jackson, R. 1981, Fantasy: The Literature of Subversion, Methuen, New York \& London.

Kayser, W. 1963, The Grotesque in Art and Literature, trans. U. Weisstein, Indiana University Press, Bloomington.

Kristeva, J. 1982, Powers of Horror. An Essay on Abjection, trans. L. S. Roudiez, Columbia University Press, New York.

—. \& Vanier, J. 2011, Leur regard perce nos ombres, Fayard, Paris.

Lerena, M. J. H. 2003, “The business of invoking humanity': Barbara Gowdy and the fiction gone (a)stray", University of Toronto Quarterly, vol. 72, no. 3 (summer) pp. 715-735.

McEwan, I. 2005, Saturday, Jonathan Cape, London.

Parpart, L. 2002, "Adapting emotions: Notes on the transformation of affect and ideology from 'We So Seldom Look on Love' to Kissed", Essays on Canadian Writing, vol. 76, pp. 51-82.

Russo, M. 1994, The Female Grotesque. Risk, Excess and Modernity, Routledge, New York \& London.

Silverman, K. 1996, The Threshold of the Visible World, Routledge, New York \& London.

Spooner, C. 2006, Contemporary Gothic, Reaktion, London.

Staels, H. 2012, "The Gothic and grotesque in Barbara Gowdy's Mister Sandman", Studies in Canadian Literature/Études en Littérature Canadienne, vol. 37, no. 2, pp. 172-191.

Sugars, C. 2014, Canadian Gothic. Literature, History and the Spectre of SelfInvention, University of Wales Press, Cardiff.

Thomson, P. 1972, The Grotesque, Methuen, New York \& London.

Zitzelsberger, H. M. 2009, "Sylvie: A reflection on embodiments and transformations", Radical Psychology, vol. 8, no. 1, n.p. available at www. radicalpsychology.org/vol8-1/ (last accessed (22 September) 2014.

Hilde Staels (Hilde.Staels@kuleuven-kortrijk.be) is associate professor of English Literature and Literary Theory at KU Leuven, Belgium. As a visiting professor at Ghent University, she teaches a master course on contemporary English-Canadian fiction. Her publications mainly focus on the techniques and formal qualities of narrative fiction. In addition to her monograph and articles on Margaret Atwood's novels, she has published articles on the Canadian authors Michael Ondaatje, Carol Shields, Ann-Marie MacDonald, Aritha van Herk, and Barbara Gowdy. 